
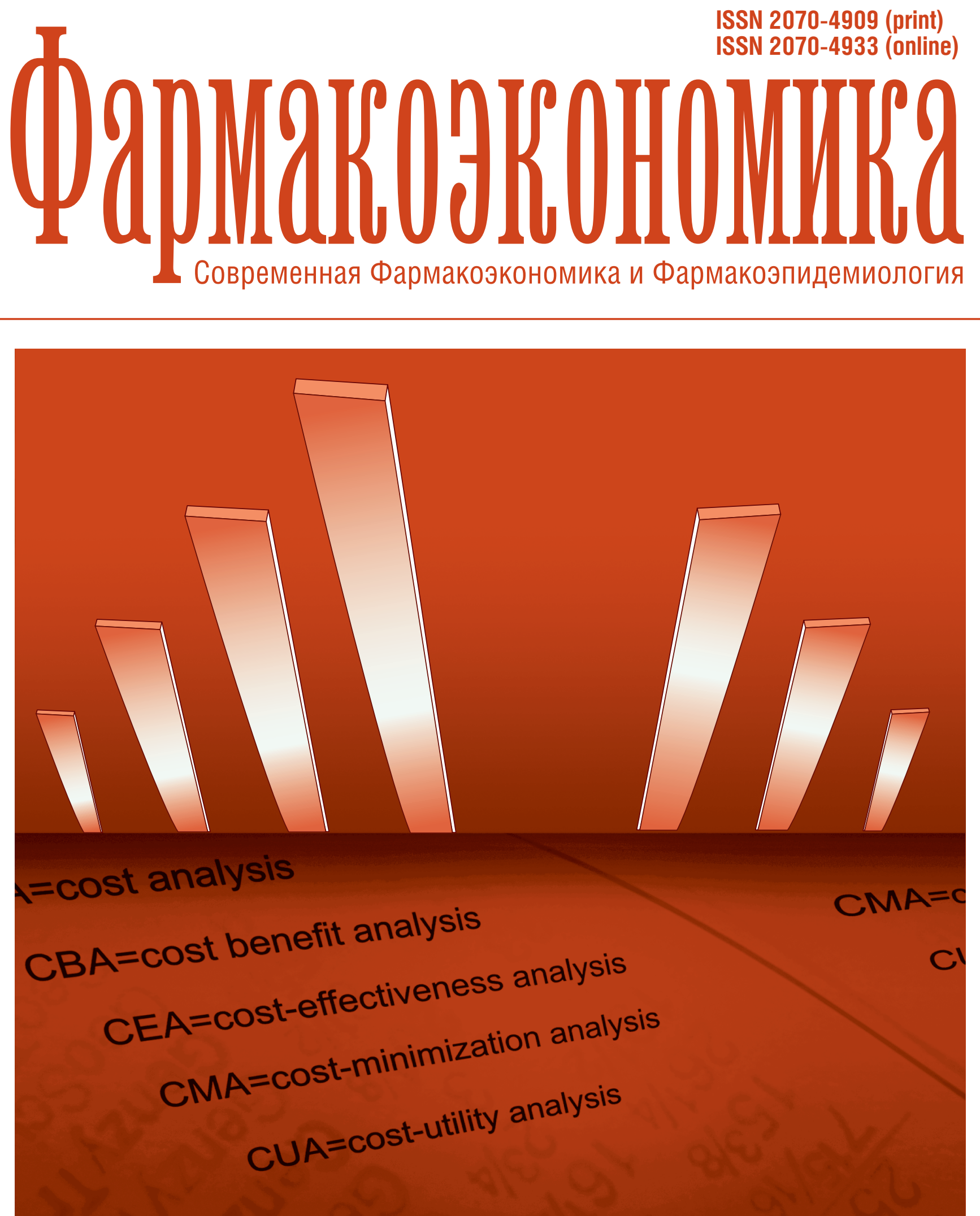

FARMAKOEKONOMIKA

Modern Pharmacoeconomic and Pharmacoepidemiology

2019 Vol. 12 No3

www.pharmacoeconomics.ru

- Формирование клинико-статистических групп для оплаты лечения злокачественных новообразований в модели 2019 года

- Доступность и фармакоэкономика инсулиновой терапии в странах с наибольшим количеством больных диабетом

- Российский опыт использования подходов к расчету потребности во врачебных кадрах

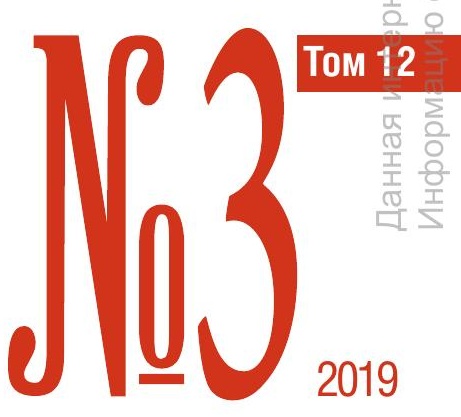




\title{
Availability and Pharmacoeconomics of Insulin Therapy in Countries with the Largest Number of Diabetics
}

\author{
S. V. Ponomarenko \\ SophiGen, Insu-Pharma AG (Siemensstraße 42, Bönen 59199, Germany) \\ For contacts: Ponomarenko Sophia Vasilievna, e-mail: ponomarenko@t-online.de
}

\begin{abstract}
Summary
The aim of the review was to analyze the availability of insulin therapy and the ways to improve it in countries with the largest number of patients with diabetes. It was also aimed to assess the medical, social and economic importance of insulin therapy and industrial production of therapeutic recombinant insulin.

Materials and methods. The analysis was based on the data taken from monographs and publications in peer-reviewed journals, reports of companies and medical organizations, and the information available in the Internet. The demand and supply in the market of recombinant therapeutic insulin, the insulin market segmentation, and the costs for insulin replacement therapy in countries with the largest number of patients with diabetes were studied.

Results and discussion. The pro- and contra- arguments regarding the import of insulin and its impact on the national budget are presented. Technological specifics of recombinant insulin production are discussed; the funding and investments in the biopharmaceutical sector are analyzed. The benefits of industrial production of recombinant therapeutic insulin and its impact on the regional and national economy are demonstrated.

Conclusion. The availability of therapeutic insulin in most countries with the largest number of diabetics is unsatisfactory and needs a radical improvement. By analyzing the economic aspects of diabetes and the pharmacoeconomics of insulin, it is advised to develop a modern management system for insulin replacement therapy, especially in countries with large numbers of diabetics. The use of innovative technologies will reduce the production costs of recombinant therapeutic insulin, increase the availability of insulin therapy and thereby improve the quality of life in diabetic patients. Evidence that the production of therapeutic insulin has a positive effect not only on the healthcare, but on the socio-economic situation in the region is also provided. Countries with a number of diabetics exceeding 5 million are encouraged to launch their own production of recombinant therapeutic insulin. The results of the present analysis confirm that half of them are able to manufacture adequate human insulin and/or its analogues.
\end{abstract}

\section{Key words}

Epidemiology and pharmacoeconomics of diabetes mellitus, recombinant therapeutic insulin, its availability and need, production of human insulin and its analogues, QALY, cost-effectiveness analysis of insulin therapy, insulin pharmacoeconomics.

Received: 28.06.2019; revised: 08.08.2019; accepted for publication: 19.09.2019.

\section{Acknowledgments}

The author would like to thank the anonymous reviewers for their insightful suggestions and the experts of the Institute for Preventive and Social Medicine for English language translation and editing.

\section{Conflict of interest}

No potential conflict of interest was reported by the author with respect to this publication.

For citation

Ponomarenko S. V. Availability and Pharmacoeconomics of Insulin Therapy in Countries with the Largest Number of Diabetics. PHARMACOECONOMICS. Modern Pharmacoeconomics and Pharmacoepidemiology. 2019; 12 (3): 178-190. DOI: 10.17749/2070-4909.2019.12.3.178-190.

Доступность и фармакоэкономика инсулиновой терапии в странах с наибольшим количеством больных диабетом

Пономаренко С.В.

СофиГен, Инсу-Фарма АГ (Сименсштрассе, 42, Бёнен, Германия)

Для контактов: Пономаренко Софья Васильевна, e-mail: ponomarenko@t-online.de

\section{Резюме}

Цель - анализ доступности инсулиновой терапии и путей ее улучшения в странах с наибольшим количеством пациентов с диабетом. Проанализирована медико-социальная и политико-экономическая значимость инсулиновой терапии и промышленного производства препаратов рекомбинантного инсулина. 
Материалы и методы. Анализ проводился на основе данных монографий и публикаций в научных рецензируемых журналах, отчетов фармацевтических компаний и медицинских организаций, а также релевантной инсормации, размещенной в сети Интернет. Изучены спрос и предложение на рынке рекомбинантного инсулина, сегментация рынка инсулина и стоимость заместительной инсулиновой терапии в странах с наибольшим количеством больных сахарным диабетом.

Результаты и обсуждение. Представлены аргументы в пользу и против импорта инсулина и его влияния на государственный бюджет. Обсуждаются технологические особенности производства рекомбинантного инсулина, анализируются фринансирование и инвестиции в биофрармацевтический сектор. Показаны преимущества промышленного производства препаратов рекомбинантного инсулина и его влияние на региональную и национальную экономику.

Заключение. Доступность препаратов инсулина в большинстве стран с наибольшим количеством больных диабетом является неудовлетворительной и требует радикального улучшения. Анализ эпидимиологических, экономических аспектов диабета и фрармакоэкономики инсулина подтверждает целесообразность разработки современной системы управления заместительной инсулинотерапией, особенно в странах с большим количеством больных диабетом. Использование инновационных технологий позволит снизить себестоимость производства препаратов рекомбинантного инсулина, повысить доступность инсулиновой терапии и тем самым продлить и улучшить качество жизни больных диабетом. В обзоре приведен пример того, что производство препаратов инсулина оказывает положительное влияние не только на здравоохранение, но и на социально-экономическую ситуацию в регионе. Странам, в которых число больных диабетом превышает 5 млн человек, рекомендуется начать собственное производство препаратов рекомбинантного инсулина. Результаты данного анализа подтверждают, что половина из них в состоянии начать производство адекватного количества человеческого инсулина и/или его аналогов.

\section{Ключевые слова}

Эпидемиология и фрармакоэкономика сахарного диабета, препараты рекомбинантного инсулина, доступность и потребность инсулина, производство человеческого инсулина и его аналогов, QALY, анализ "затраты-эфффективность" инсулиновой терапии, фрармакоэкономика инсулина.

Статья поступила: 28.06.2019; в доработанном виде: 08.08.2019; принята к печати: 19.09.2019.

\section{Консрликт интересов}

Автор заявляет об отсутствии необходимости раскрытия финансовой поддержки или конфрликта интересов в отношении данной публикации.

\section{Для цитирования}

Пономаренко С.В. Доступность и фрармакоэкономика инсулиновой терапии в странах с наибольшим количеством больных диабетом. ФАРМАКОЭКОНОМИКА. Современная Фармакоэкономика и Фармакоэпидемиология. 2019; 12 (3): 178-190. DOI: 10.17749/2070-4909.2019.12.3.178-190.

\section{Introduction}

Diabetes mellitus (DM), as defined by the World Health Organization (WHO), is "a chronic metabolic disease characterized by elevated levels of blood glucose, which leads over time to serious damage to the heart, blood vessels, eyes, kidneys and nerves" [1]. This progressive disease occurs when the body does not synthesize enough insulin or when it cannot effectively use produced insulin [2-4].

Insulin is an anabolic hormone synthesized in beta-cells of the pancreas. The physiological action of insulin manifests in a significant drop of blood glucose concentration. The exogenously administered insulin termed the insulin replacement therapy (IRT) is a vital medication for diabetes in children and adults [3-8]. A condition in which glucose concentration is significantly higher than physiological is called hyperglycemia. In the IRT, recombinant insulin (rl) is predominantly used $[4,6-8]$.

According to the $\mathrm{WHO}$, the number of patients with diabetes increased fourfold from 1980 to 2014 [2]. In 2017, 425 million people on Earth suffered from this disease (Fig. 1) and, according to the International Diabetes Federation (IDF), about half of them live with undiagnosed diabetes [5]. More than $70 \%$ of patients with DM live in 14 countries (Fig. 2), referred to as countries with the largest number of diabetics (LND). In these countries, the number of people with impaired glucose tolerance is also the highest one [5]. In the LND countries, the number of diabetic patients varies from 5 to 114 million, with the prevalence of DM from 6.2 to $17.3 \%$; that is, in countries with LND, on average, $9.6 \%$ of the adult population have this metabolic syndrome (Fig. 3) [5].

Tackling a disease of such epidemic proportions [2] requires excessive expenses (Fig. 3-5), which often leads to a disproportionate increase in health care costs and adversely affects the social budget, the health care system and the national economy, especially in the LND countries [9-10]. Most countries have developed programs for prevention and treatment of diabetes as recommended by the WHO $[2,4]$. The development of the Diabetes program is especially important for countries with LND. Several reputable international and national organizations, including the WHO, IDF and the International Insulin Foundation (IIF) emphasize that the availability of IRT is vital for patients with diabetes.

Aim - analyze the availability of insulin therapy and the ways to improve it in countries with the largest number of patients with diabetes. It was also aimed to assess the importance of industrial production of recombinant insulin in the medical, social and politicaleconomic aspects.

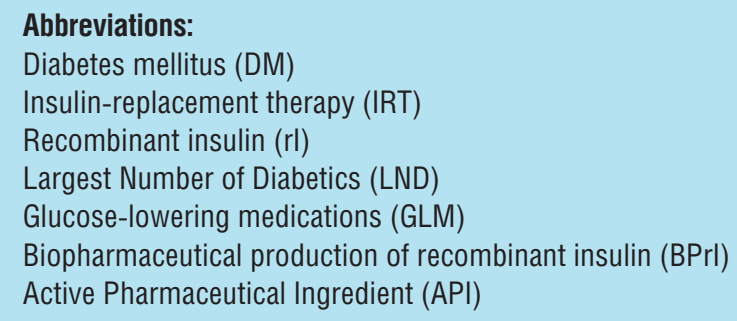

\section{Materials and Methods}

The following sources were used for this review and analysis: monographs on diabetes, therapeutic insulin, production of recombinant therapeutic proteins and their pharmacoeconomics; scientific publications in peer-reviewed journals, reports and releases from companies (www.lilly.com, www.novonordisk.com, www.sanofi. com, www.biocon.com, www.bioton.pl, www.geropharm.ru, www. julphar.net, www.scigenltd.com) and organizations (American Diabetes Association, ADA; European Medicines Agency, EMA; 
International Diabetes Federation, IDF; IDRF; India Diabetes Research Foundation, International Insulin Foundation, IIF; JDRF; Juvenile Diabetes Research Foundation, The Pharmaceutical Research and Manufacturers of America, PhRMA; World Health Organization, WHO) as well as the information from the Internet sites (www.biopharmax. com, www.gelifescience.com, www.haiweb.org, www.patentgoogle. com, www.sigmaaldrich.com).

The data reflecting the needs for insulin, the market of recombinant insulin in various regions, the costs for insulin replacement therapy in countries with LND were analyzed. The pros and contras of the recombinant insulin import versus its local production were compared. The risk assessment of investing into the recombinant insulin production was performed using the SWOT and PEST analyses.

\section{Results and discussion}

\section{Financial aspects of diabetes care in countries with a large} number of diabetics

Great progress has been made in the diagnosis and treatment of diabetes; however, in countries with LND, especially those with low or lower-middle incomes, a significant part of diabetic patients do not receive an appropriate treatment [11-15]. For patients with diabetes in India, Bangladesh and Pakistan, IRT is unaffordable (see Fig. 4). Recently, WHO issued a statement: "Governments and other interested parties should give priority to ensuring affordable and equitable access to insulin, a vital drug for people with diabetes" [2]. IIF experts have developed a protocol that can facilitate the availability of IRT [16].

IRT is vital for patients with type 1 diabetes mellitus (T1DM); they need insulin for life $[3-4,6]$. More than $90 \%$ of patients diagnosed with DM suffer from type 2 diabetes mellitus (T2DM) [4-5,7]. To prevent hyperglycemia, patients with T2DM are prescribed, first-line, oral glucose-lowering medications (GLM), and only then - insulin injections or a combination of both [3-4,7]. Oral GLM are usually cheaper than insulin [2], therefore, in low-budget health systems, the authorities prefer oral GLM monotherapy or their combination that saves budget but may cause irreparable damage to patients.

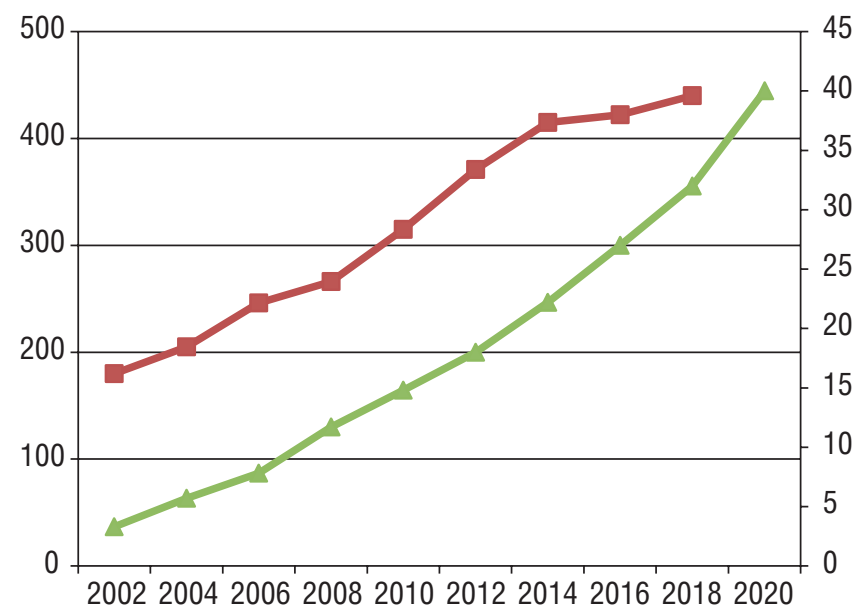

Figure 1. The number of people with diabetes and the global sales of recombinant insulin.

Note. The number of patients (in millions) suffering from diabetes (red line) is indicated on the left ordinate axis; the sales volume (green line) is indicated on the right ordinate axis in billions of USD [1-2, 5, 22, 65, https://diatribe.org/search/ advanced/rising\%20cost\%20insulin, https://www.zionmarketresearch.com/sample/ human-insulin-market].

According to the global sales figures, less than $10 \%$ of diabetics currently receive insulin for glucose lowering treatment (see Fig. 1). Long-term observations have shown that uncompensated hyperglycemia leads to the development of serious complications, such as: heart attack, stroke, blindness, and damage to kidneys and other organs [3] that may result in early disability or premature death $[2,11,17-19]$. Treatment of complications caused by uncontrolled diabetes is several times more expensive than the cost of high effective IRT. In North America, the EU and Japan, $80-90 \%$ of diabetic patients receive IRT if prescribed [2, 4-5]. In the United States of America (US), Germany, Brazil and Japan, the health care expenses per GDP are the

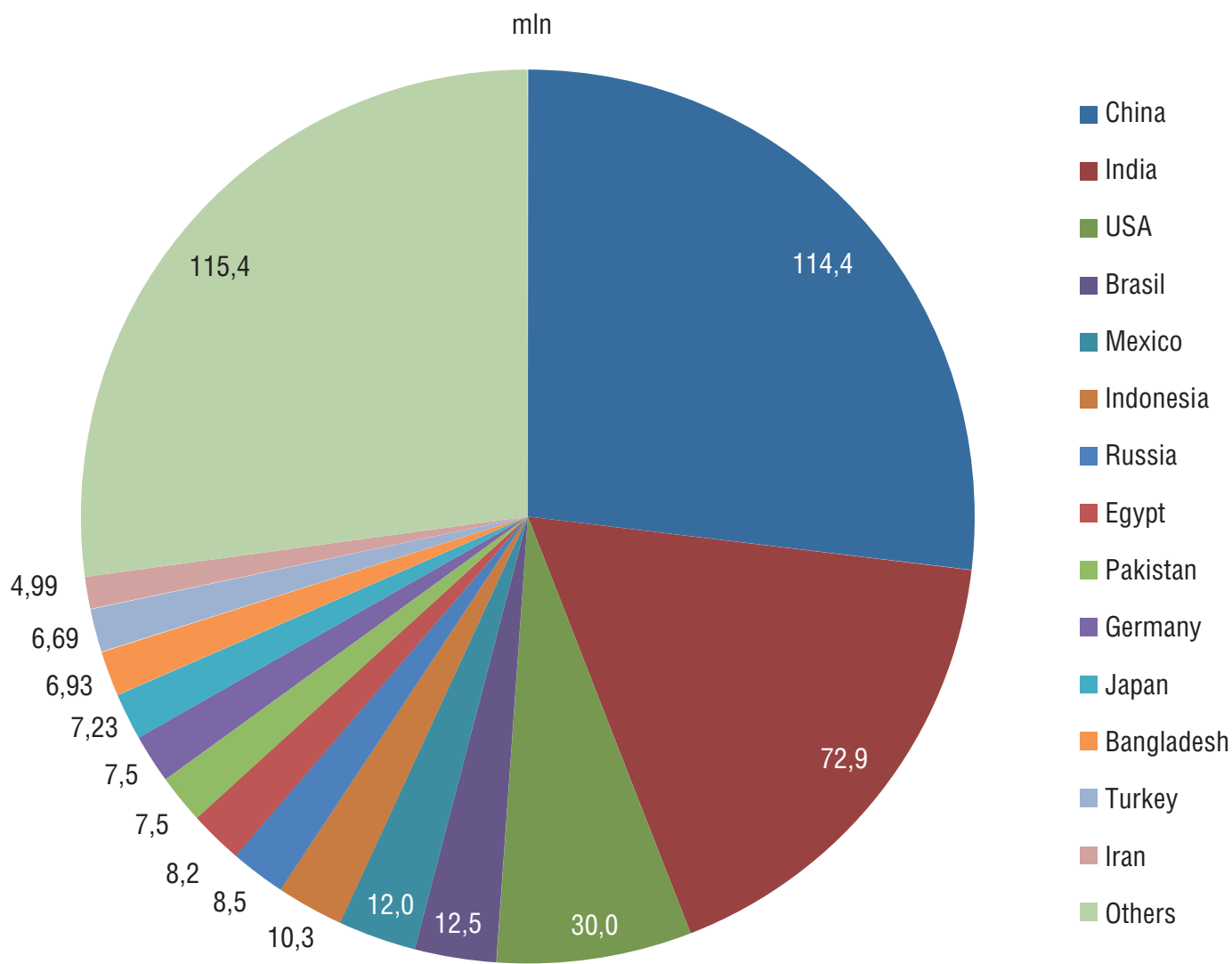

Figure 2. The number of patients (million) with diabetes in countries with the largest number of diabetics around the world in 2017 according to the IDF report [5]. 


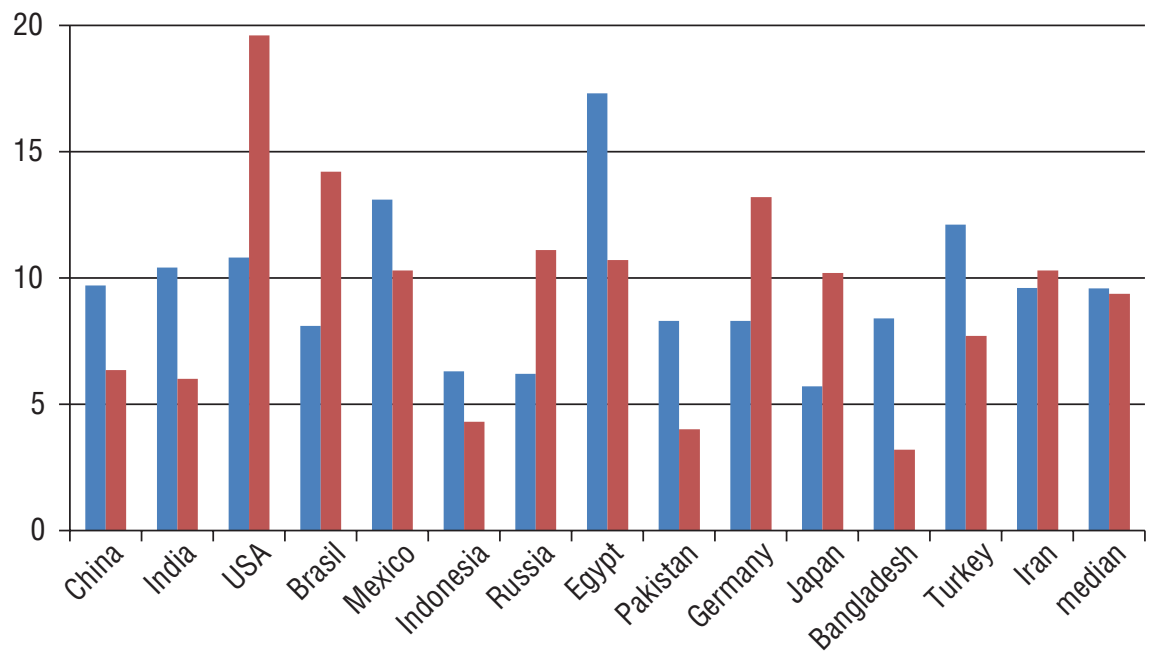

Figure 3. Prevalence of diabetes and the level of spending per patient in countries with the highest number of diabetics.

Note. The diabetes occurrence rate as percentage of the adult population (blue) [2, 5]; the ratio (\%) (red) of the spending per patient [2, 5] to the nominal GDP per capita in 2016-2017 [World Economic Outlook Database-April 2018, International Monetary Fund].

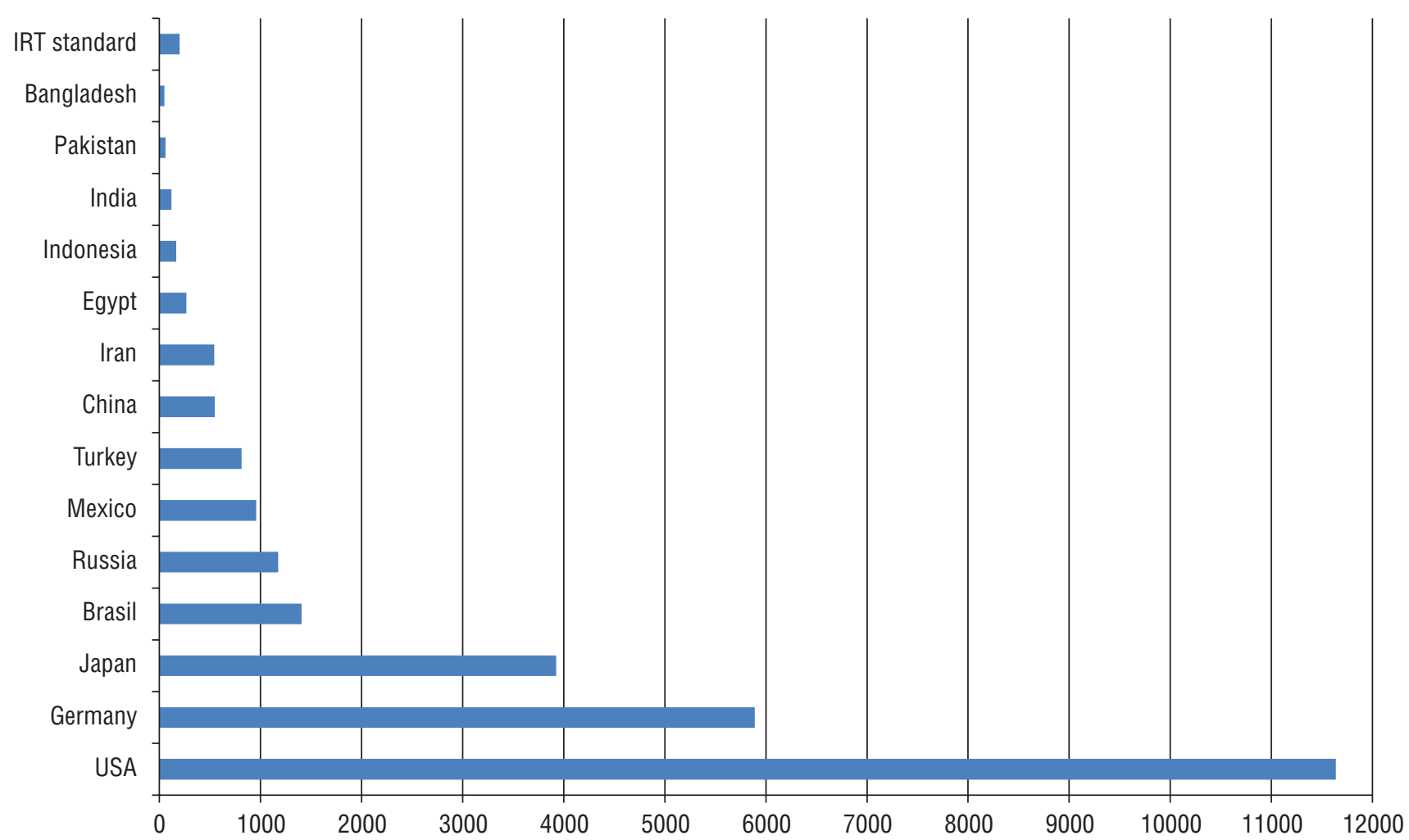

Figure 4. Direct costs of treating one patient with diabetes per year (in USD) [5]. The cost of the standard insulin replacement therapy (IRT standard) is taken from report [2].

highest in the LND countries as well as the diabetes treatment funding is higher than the average one (see Fig. 5). In countries with a high prevalence of diabetes - Egypt, Mexico, Turkey, and US - the expenses for diabetes care exceed $10 \%$ of the total health care budget (see Fig. 5).

In the high income LND countries, there is a government-established system of prevention and control of hyperglycemia; accordingly, the quality and duration of life of patients with diabetes in these countries is high $[2,5]$. In four Asian countries with LND, the diabetes control programs are poorly funded, and the total costs of treatment for diabetes are several times lower than that recommended by the standard IRT guidelines (see Fig. 4-5).
Almost half of all diabetics in the world live in two giant countries (China and India) (see Fig. 2). The US holds the third place by the number of patients with DM. The US is the world leader in health care costs; more than $16 \%$ of the national health budget is allocated for the care of diabetes and related complications [17,20,21].

In each of the 13 countries shown in Fig. 2, the number of diabetics exceeds 6 million. In Iran in 2017, there were almost 5 million diabetics (see Fig. 2). Figures 4 and 5 show that in some countries with LND, the cost of treating patients with DM is too high for the health care budget and (according to specialists) the costs will increase as the number of diabetics and their life expectancy will rise [22]. 


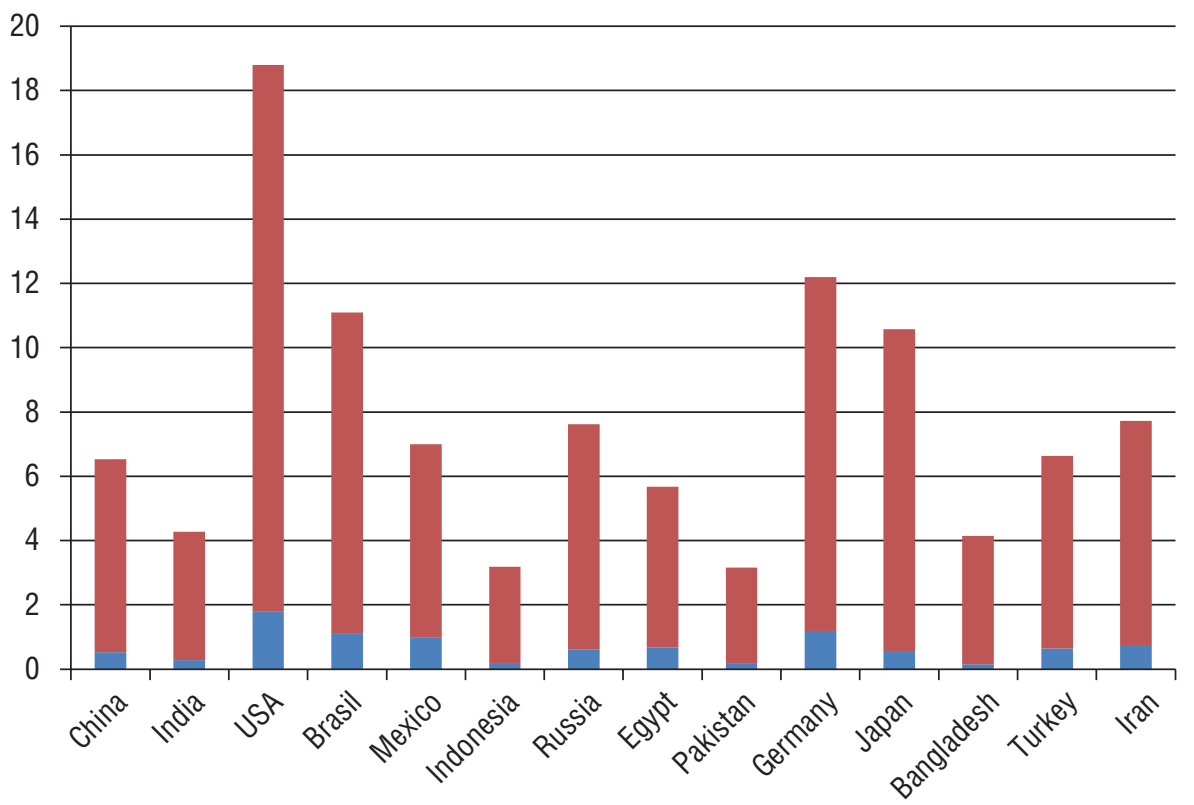

Figure 5. Total health care costs and the costs of diabetes treatment in countries with the largest number of diabetics. Note. Level of health care expenditure as percentage of the GDP(red) (Current health expenditure per capita (USD) [https://data.worldbank.org/indicator/SH.XPD.CHEX. PC.CD] including the expenditure for diabetes as percentage of the GDP (blue) [5].

According to the IDF, the total global cost of prevention and treatment of diabetes and its complications more than tripled between 2003 and 2013 due to the growing number of adults living with DM and the increased cost of their treatment. The direct costs of providing medical care to diabetics (aged 20-79 years) worldwide reached USD 727 billion in 2017, while the US only spent 327 billion [17]. In the same year, India (see Fig. 2.), which ranks second in the world in terms of the number of diabetics (more than $17 \%$ of all diabetics in the world), spent only 7.23 billion dollars for their DM care [5], or about $1 \%$ of the global diabetes spending's; this amounted to more than $10 \%$ of the national health budget, which is above the average level for countries with LND (see Fig. 3). The total expenses for diabetes care, as well as the expenses per patient differ by tens or even hundreds of times between countries with low and high income (see Fig. 4, 5). The annual cost of treatment of one diabetic patient was 100 times (in 2010) and 200 times (in 2017) higher in the US than in Southeast Asia [20]. In 2017, the health care of one DM patient in the US cost about USD 12,000 per year, whereas in Pakistan, the respective figure was 62, and in Bangladesh - USD 51 [5.17] (see Fig. 4). According to the WHO forecasts, the overall picture of diabetes-associated morbidity and mortality is not expected to change in the coming years. If the insufficient funding of diabetes care continues, the global losses from this disease will reach USD 2.2 trillion in 2030 and will have a heavy impact on the economies of LND countries [9,18-19].

The heavy economic burden of diabetes, especially in low and lowmiddle income countries, is manifested not only in the high national expenditure, but also (and most of all) in the family payment for treatment of diabetes and its complications, as well as the income losses due to disability [9,17-18,20-21].

The cost of IRT is less than $20 \%$ of the direct expenses associated with DM [23]. To reduce the direct and indirect costs, the society has to provide an access to insulin therapy for all patients with diabetes, as recommended by the WHO, IIF and IDF; this is relevant for each region and, above all, for countries with LND.

\section{Economic and social aspects of insulin replacement therapy in} countries with a large number of diabetics

Since it was first used in clinical practice, therapeutic insulin has proved to be a human natural GLM that specifically and effectively reduces blood glucose levels in patients with all types of DM [3-4, 6] and thus provides for the extension and improvement of millions of lives. The absence or unavailability of this medication is a lifethreatening event for diabetics receiving IRT.

Long-term randomized multicenter studies in North America (DCCT / EDIC and PDP) and Europe (UKPDS) have shown socio-economic benefits of IRT because optimal control of diabetes reduces the overall costs associated with this disease [3-4, 6-7]. The results of these studies in combination with the data on epidemiology and economics of diabetes and pharmacoeconomics of insulin therapy can be used for optimizing the antidiabetic budget in countries with LND (see Fig. 2). In countries with advanced life expectancy, the number of diabetics is high; there, a significant proportion of patients with long-term T2DM have to be treated with insulin to compensate for progressive hyperglycemia [3, 5-7, 19].

In the EU countries and the US, about one-third of diabetics receive IRT, but in countries with low or low middle incomes, including those with LND, insulin is hardly affordable for most patients (see Fig. 4). In the Asian countries with LND, the funding for the treatment of diabetics is inappropriately low (see Fig. 3). Health budget as a percentage of GDP in India, Indonesia, Pakistan and Bangladesh is 3-5 times lower than that in the US, Germany, Brazil or Japan; the difference in the diabetes-associated spendings between the first and second groups of countries is even greater (see Fig. 5). In LND countries with low-budget health care that rely on insulin import, the main problem is the availability of therapeutic insulin $[2,11-13,20]$.

Due to the high number of consumers, the emerged markets in countries with LND are especially attractive to insulin manufacturers. Until 2015, an insignificant part of rI was produced in nine countries with LND (see Fig. 2). In the US, a full range of blockbuster rl products are manufactured. Germany as part of the EU, also obtains all required types of therapeutic rl.

Some companies from India and China produce a cheaper version of rl using their own technology (about $10 \%$ of the domestic rl market); yet the quality of this product does not meet the requirements of the European Pharmacopoeia (EP/EMA) or the US Pharmacopeia (UP/ FDA). That is, the availability and quality of insulin under the public procurement program in LND countries (see Fig. 3) depends on social strategy, as well as on the structure and sustainability of the financial 
system in these nations. According to experts in diabetic care, the socio-political and socio-economic priorities of the government can be assessed by how timely and what quality of IRT the national program provides [2].

Insulin is leading the growth rate in sales of biopharmaceuticals because the number of IRT- dependent diabetics is on the rise, and because these patients need to gradually increase the dose after years of insulin (see Fig. 1). From 2004 to 2018, the number of diabetics in the world increased almost 2.2-fold. During these years, the volume of commercial sales of human $\mathrm{rl}$ and its analogues increased more than 5 -fold (see Fig. 1). According to experts in pharmacoepidemiology and pharmacoeconomics, this trend in the rl sales (5-8\% per year) will continue for the next 5 years $\mathrm{s}^{\mathrm{a}, \mathrm{b}, \mathrm{c}, \mathrm{d}}$. The stable growth of the insulin market (see Fig. 1) is a practical confirmation of the economic feasibility of IRT.

Understanding the economic and social aspects of diabetes care, governments of LND countries intend to start the complete production (comprising up- and down-stream, and filling) of their own insulin. In some of these countries, attempts were made to develop high-quality and low-cost rl using their own technology; yet, setting up a production line proved to be an impossible task. Biopharmaceutical production of recombinant insulin (BPrl) requires significant investments and special types of cooperation, including the participation of experts in epidemiology of diabetes and pharmacoeconomics of insulin, in order to avoid imbalances in the budget.

Thus, economics of diabetes is an important discipline for analyzing the national health budget, as the direct and indirect costs for daily therapy, for preventing and treating the complications of DM, including the losses due to disability, can reach a significant part of the healthcare budget, like it happens in the US $[14,17]$ and other countries with LND (Fig. 4-5). Therefore, the epidemiological and pharmacoeconomic considerations are crucial for developing of antidiabetic programs and for planning of public health budget in countries with LND. This approach will help overcome economic and social barriers concerning the availability of insulin therapy in countries with a large number of diabetics.

\section{Types of recombinant insulin, its production and market, the price of insulin replacement therapy}

The insulin market, like any other medicine market, is characterized not only by the demand but also by the purchasing power of the consumer. In 2015, the rl sales reached USD 25 billion (see Fig. 1), but the global demand was $3-4$ times higher $[13,24]$.

Unlike many genetically engineered biological blockbusters, insulin is not a monopoly, but an oligopoly product. Until recently, three competing pharmaceutical companies - Novo Nordisk (Bagsvaerd, Denmark), Sanofi (Paris, France) and Eli Lilly (Indianopolis, US) produced about $96 \%$ of the global insulin that met the quality requirements of EMA and FDA $[10,20,25]$. This dominating triumvirate determines the policy of production, pricing and marketing of therapeutic rl. Such companies as Biocon (India), Julphar (United Arab Emirates), Tonghua Dongbao Pharmaceutical Co. Ltd., Gan \& Lee

a Human Insulin Market All Geared Up For Rapid Development With Expected Growth Of USD 43.6 Billion By 2021. [Electronic resource]. URL: https://www.zionmarketresearch.com/news/global-human-insulinmarket. Accessed: 26.06.2019.

b Human Insulin Market Overview. [Electronic resource].URL: https:// www.psmarketresearch.com/market-analysis/human-insulin-market. Accessed: 26.06.2019.

c Global Basal Insulin (Long-acting insulin) Market - Growth, Trends and Forecast (2019-2024). [Electronic resource]. URL: https://www. mordorintelligence.com/industry-reports/insulin-market. Accessed: 26.06.2019.

d Estimated global human insulin market revenue from 2015 to 2021. [Electronic resource]. URL: https://www.statista.com/statistics/731843/ human-insulin-revenue-worldwide. Accessed: 26.06.2019.
(China), Bioton (Poland), Geropharm (RF) are active in Asia and Europe, where they sell rl manufactured according to their own patents and technology [26].

By its pharmacokinetic profile, commercial recombinant insulin is produced as a short-, regular-, or long-acting hormone. Information about the properties of $\mathrm{rl}$, its mixed forms, and numerous trademarks is available on the websites of manufacturers and pharmacies [26]. Endocrinologists use the insulin pharmacokinetics to develop daily or long-term pharmacodynamics of glucose adjusted to the clinical characteristics of a patient $[3-4,6]$.

The increase in sales of $\mathrm{rl}$ products has so far occurred by $11 \%$ per year, mainly due to the expansion of US and EU markets of the innovative insulin analogues of fast or prolonged action, which are modifications of the human insulin molecule. Two insulin analogs Lantus and Aspart are among the top 10 best-selling therapeutic recombinant proteins.

The success of Lantus (insulin glargine) in the treatment of DM stimulated the production of its biosimilars by the US pharmaceutic giants Lilly, Merck and Mylan [27-29]. In parallel, the annual sales of prolonged insulin analogues produced by Sanofi and Novo Nordisk in the US fell by more than 3 billion USD.

The global market of $\mathrm{rl}$ products is far from saturation (see Fig. 1), therefore, the manufacturers are going to determine the market sectors and prices for hormone replacement therapy for quite a while [10, 12, 26, 30].

Experts predict that due to the prolonging life expectancy of diabetics, the gradually increasing dose requirements, and new cases of DM, the rl sales will increase [25, 27-29, 31-34]. The above factors together with the growing production of biosimilars may change the insulin market segmentation in the way it happened in 2015 with the basal insulin analogues. Manufacturers of the original preparations warn of the danger of insulin biosimilars [35]. Other researchers are confident that $\mathrm{rl}$ biosimilar are fully consistent with the safety and efficacy of the original drug $[32,34,36]$. Full saturation of the rl market by national manufacturers (like it takes place in the US) has not yet been implemented in any country. The WHO plans to increase the availability of essential medicines, including insulin up to $80 \%$ before 2025 [1]. In order to solve such a global problem, it is necessary to significantly increase the production volume, considerably reduce prices of the $\mathrm{rl}$ and its delivery.

The cost of IRT depends on the type of insulin and its formulation. The price of human insulin packed in large $(10 \mathrm{ml})$ vials is the lowest per unit of insulin activity; this package is commonly used in the hospital settings [12]. This preparation with a specific activity of $100 \mathrm{IU}$ is recognized as a standard for insulin therapy $[2,30]$. In this case, the average cost of annual therapy varies from 80 USD to 240 USD depending on the region $[2,12,37]$. In pre-filled syringe pens, the price of insulin injections is $25-75 \%$ higher than the above standard [2, $30,37,38)$. A single-use pre-filled insulin syringe is safer and easy to use for injection and dosing [39-40]; therefore, despite the higher cost, such syringe pens are preferably recommended for children and elderly patients.

The production of $\mathrm{rl}$ analogues is usually more expensive than that of human insulin, so their price is 2-5 times higher (depending on the region). As a result, the cost of injection using a pre-filled syringe pen with an innovative insulin analogue can be several times higher than the standard formulation [12,30,38-40].

A number of clinical studies have shown that using more expensive insulin analogues may ultimately prove to be more cost-effective than therapy with human rl. For example, several randomized studies showed that dangerous nocturnal hypoglycemia occurs less frequently with the prolonged insulin preparations glargine and detemir (Lantus and Levemir) than under therapy with other $\mathrm{rl}$ products [7, 41-46]. More than half of the Lantus and its biosimilars manufactured by the three pharmaceutical giants are used inside the US; most patients prefer pre-filled insulin pens $[17,25]$. 
The biopharmaceutical sector is a rapidly growing part of the global market with its increasing influence on the financial, political and informational components. The US can be called the "global pharmacy", as more than half of all medicines, including recombinant therapeutic proteins, are manufactured in this country [47].

For most countries with LND, imported biopharmaceuticals are more expensive than domestic products, especially if they are made in high-income countries. In addition to the high prices, imports of therapeutic insulin have a number of other negative factors; however, they can be counter balanced by positive factors as can be seen from Table 1.

\section{Specifics of recombinant insulin production}

According to the WHO recommendations, the absolute majority of diabetic patients use genetically engineered insulin for the IRT. Technological details of rl production - the gene expression system, the conditions for the recombinant polypeptide biosynthesis, the processes of protein purification and insulin formulation - have been well known for a long time [32,48-51]. Pure rl can be obtained in the laboratory rather quickly as it is a well-expressed heterogeneous protein [48,52]. Recently, a group of volunteers in the US announced their intention to produce very cheap $\mathrm{rl}$ in a conventional laboratory in framework of the open project Biohacking Insulin [53]. However, the production of high-quality and certified commercial insulin, like other recombinant therapeutics, is very expensive in the US and the EU, so the prices of these biopharmaceuticals remain high $[8,30]$.

Obtaining the active pharmaceutical ingredient (API) of insulin from cultured cells is a complex and expensive multi-step process ${ }^{\mathrm{e}}$ associated with organizational measures to meet the requirements of EP/EMA or UP/FDA and to allow this product to be used for injection $[24,27,29,33]$. To date, several technologies with some different characteristics have been developed to produce the $\mathrm{rl}$ on an industrial scale $[31,33,50-51,54,55]$. To get an optimally developed biopharmaceutical technology, well-trained specialists are needed.

e Biocon Virtual Tour. [Electronic resource]. URL: http://www.biocon.com/ bioconvirtualtour_v1/. Accessed: 26.06.2019.
The first step of the rl production is to construct a highly productive strain of the specific microorganism that provides for stable and highyield synthesis of recombinant protein. For the controlled biosynthesis of recombinant protein, large bioreactors with a huge amount of nutrient medium are used, which makes the up-stream stage quite expensive.

The next step - isolation and purification of the target protein to obtain API insulin - is called the down-stream step; this one is even more expensive [50]. The down-stream process consists of more than 30 stages; at each stage, a considerable part of the product is unavoidably lost, which significantly reduces the final yield and ultimately leads to the high cost of the end-product.

The notion that the down-stream stage of the production is the most expensive one is evidenced by the prices offered by insulin suppliers, where highly purified recombinant protein is several times more expensive than the primary protein $n^{\mathrm{f}, g}$

The costs of recombinant protein production depend on the level of protein expression and on the efficiency of the down-stream stages. The costs are also determined by the capacity of the factory; therefore, the proposed projects for industrial insulin production must be carefully evaluated [56,57]. From the practical experience of others, the production exceeding 1.5 tons of $\mathrm{rl}$ can be profitable $[24,58]$. This amount of $\mathrm{rl}$ is sufficient to cover the needs of about 1.5 million patients, which is $30 \%$ of the 5 million diabetics receiving IRT; these figures are in line with the recommendations of endocrinologists and the therapy standards for diabetes [3-4,6].

Production capacity of 1.5 tons will cover the need for IRT in Iran. In other countries with LND and a high need for insulin, much more rl of various types must be produced.

The development of a technological scheme that ensures a high yield of the product of required purity is extremely important. To optimize the production process, researchers are looking for time-and

$f \quad$ SIGMA-ALDRICH Insulin. [Electronic resource]. URL: https://www. sigmaaldrich.com/catalog/search?term=insulin\&interface. Accessed: 26.06.2019.

g Recombinant Human Insulin. [Electronic resource]. URL: https://www. kerafast.com/product/1179/recombinant-human-insulin. Accessed: 26.06.2019.

Table 1. Negative and positive effects of insulin imports on the national budget.

\begin{tabular}{|c|c|c|}
\hline Negative factors & Positive factors & Notes \\
\hline $\begin{array}{l}\text { High prices for therapeutic insulin, so IRT is } \\
\text { not available to everyone in need }\end{array}$ & $\begin{array}{l}\text { Unlike the local start of manufacturing, } \\
\text { imports do not require large investments }\end{array}$ & $\begin{array}{l}\text { It is possible to pay according to a strategic } \\
\text { plan in a flexible and gradual manner upon } \\
\text { receiving the import product }\end{array}$ \\
\hline $\begin{array}{l}\text { Dependence on drug supplies from abroad } \\
\text { that may be disrupted from time to time }\end{array}$ & $\begin{array}{l}\text { Some patients can pay for treatment from } \\
\text { their own funds, without waiting for } \\
\text { purchases under the social program }\end{array}$ & $\begin{array}{l}\text { In China, up to } 60 \% \text { of the treatment costs are } \\
\text { paid by patients from their own funds, in India } \\
\text { it is even higher - up to } 80 \%\end{array}$ \\
\hline $\begin{array}{c}\text { The supplier may change the selling prices } \\
\text { depending on global demand and the amount } \\
\text { of insulin produced }\end{array}$ & $\begin{array}{c}\text { For large volume orders, it is possible to } \\
\text { organize a tender or select a different } \\
\text { supplier and also dictate the range and } \\
\text { conditions of the supply }\end{array}$ & $\begin{array}{l}\text { Prices for branded biological products, } \\
\text { including insulins in low- or lower middle- } \\
\text { income countries may be lower than in } \\
\text { Europe and the US }\end{array}$ \\
\hline $\begin{array}{l}\text { Major insulin manufacturers can dictate their } \\
\text { terms conditions of drug sales }\end{array}$ & $\begin{array}{c}\text { Often there is a choice between price and } \\
\text { quality from several suppliers. Some patients } \\
\text { may pay extra from personal funds for } \\
\text { exclusive drugs }\end{array}$ & $\begin{array}{l}\text { For branded drugs in the US, patients must } \\
\text { pay extra from their personal funds }\end{array}$ \\
\hline $\begin{array}{c}\text { Support for production, research and } \\
\text { technology of the exporting country, but not } \\
\text { the importing one }\end{array}$ & $\begin{array}{c}\text { Targeted delivery and limited quantities } \\
\text { increase the control over distribution and } \\
\text { prevent resale or misuse }\end{array}$ & $\begin{array}{l}\text { Information about the intended use of IRT is } \\
\text { helpful for creating a real database, receiving } \\
\text { reports, and analyzing the mandatory } \\
\text { "cost-effectiveness" data regarding the } \\
\text { therapy }\end{array}$ \\
\hline $\begin{array}{c}\text { Branded insulins are formulated using modern } \\
\text { means of drug delivery, which makes insulin } \\
\text { therapy very expensive }\end{array}$ & $\begin{array}{l}\text { Low-income countries mainly use the } \\
\text { cheapest insulin supplied in vials }\end{array}$ & $\begin{array}{l}\text { Brand-name insulin manufacturers provide } \\
\text { high efficacy, proven safety, and the best } \\
\text { pharmaceutical quality }\end{array}$ \\
\hline
\end{tabular}

Note. IRT - insulin replacement therapy. 
material-saving solutions that fit into modern recombinant blockbuster technologies. Therefore, manufacturers patent not only the recombinant genes and the expressing constructs but also the methods for obtaining primary insulin and for purification the proteohormone, as well as the methods for formulating API and for improving the drug delivery [59$60]$.

\section{Economic aspects of recombinant insulin production}

In contrast to low-molecular generics, rl like other biopharmaceutical blockbusters faces extremely high barriers before entering the market of biosimilars $[25,61]$. It is worth mentioning that the pre-sale period of a new product lasts about 3 years, therefore, the return of the investments becomes optimal only after several years [61-63].

Thus, the production of high-quality, competitive and commercially viable biopharmaceutical blockbuster is a high-cost and long-term project with a risk of unforeseen losses $[25,57,61]$. Successfully implementing such a project is more feasible in high-income countries with high regulation of the pharmaceutical market. An organization with a strong budget, stable partnerships and right financial connections has good chances to launch an insulin production facility. The big biopharmaceutical companies in India and China, as well as manufacturers in other countries with LND, have so far failed to start production of $\mathrm{rl}$ biosimilars with a radically lower price in order to make insulin therapy affordable for diabetic patients in their countries. In the pharmacoeconomic aspects, IRT is affordable and even cost-effective for patients in the US, Germany and Japan, but expensive for patients in other countries with LND, and unaffordable for most diabetics in India, Bangladesh and Pakistan (see Fig. 4-5). For countries with LND, which need large purchases of insulin (see Fig. 2), it is especially important to make a timely choice: to continue importing or start independently producing the required amount of $\mathrm{rl}$ (see Table 1).

Efficacy of IRT is individual: some patients prefer human insulin, others - its analogues or even pork insulin. Establishing the production of several different types of high-quality insulin in countries with low rl demand and only for the domestic market is economically unprofitable; yet, countries with LND, major importers of insulin, should develop their own sovereign production of various rls.
The production of recombinant therapeutic proteins can be highly cost-effective, but doubts about successful completion of the project and its financial risks prevent developers from investing in the production of biological products or biosimilars. The recent innovations in the up-stream and down-stream phases of insulin production have to optimize the rl costs so that the IRT has become more affordable and even cost-effective [64]. For an enterprise such as rl production, the investor should realistically assess the cost-benefit and costeffectiveness of this project. The known risks and their impacts are recently discussed by others [57,62-63].

In addition to the barriers impeding the access to $\mathrm{rl}[13,14,16,57]$ and the pro and contra arguments on the insulin import in countries with LND (see Table 1), other instruments like the SWOT-analysis and PEST-analysis can help the interested parties to make the best decision. SWOT is an acronym for English words Strengths, Weaknesses, Opportunities, and Threats. Recently, a company that manufactures high-tech equipment for insulin quality testing made a good use of-SWOT analysis [65]. Table 2 summarizes the strengths and weaknesses of rl production, as well as potential opportunities and threats associated with promoting rl sales in the market.

PEST (Table 3) refers to the analysis used to identify Political, Economic, Social, and Technological factors that have an impact on the implementation of a rl project.

Each element of SWOT and PEST analyses may include a wide range of factors contributing to the risk level. The PEST analysis for the project shown in Table $\mathbf{3}$ includes important general factors (as for any innovative production) and also the factors with a direct impact on the production and market of recombinant insulin. The PEST analysis for experts in the field of pharmacoeconomics has its own characteristics. Recently, a PEST analysis for the biopharmaceutical industry including recombinant insulin manufacturers ${ }^{\mathrm{h}, \mathrm{i}}$ was presented [66].

There are supporters and opponents for both the import and the domestic production of recombinant insulin. Therefore, experts in DM epidemiology and $\mathrm{rl}$ pharmacoeconomics have an important say in

h Sanofi SWOT and PESTLE Analysis. [Electronic resource]. https://www. swotandpestle.com/sanofi/. Accessed: 26.06.2019.

Novo Nordisk SWOT \& PESTLE Analysis [Electronic resource]. https:// www.swotandpestle.com/novo-nordisk/. Accessed: 26.06.2019.

Table 2. SWOT-analysis of factors crucial for decisions on the funding of the project of recombinant insulin production.

\begin{tabular}{|c|c|c|}
\hline Factors & Strengths (S) & Weaknesses (W) \\
\hline \multirow{4}{*}{$\begin{array}{l}\text { Internal } \\
\text { factors }\end{array}$} & $\begin{array}{l}\text { The use of innovative methods and modern technologies } \\
\text { significantly reduces the cost of therapeutic protein production }\end{array}$ & $\begin{array}{l}\text { High cost of recombinant insulin production } \\
\text { Low yield of the final product }\end{array}$ \\
\hline & $\begin{array}{l}\text { The manufacturer determines the price of the product. } \\
\text { The price of the sought-after therapeutic insulin includes a margin } \\
\text { that meets the requirements of both investor and manufacturer }\end{array}$ & $\begin{array}{l}\text { High price of insulin therapy, external pressure on the } \\
\text { selling prices }\end{array}$ \\
\hline & $\begin{array}{l}\text { The global market of recombinant insulin is constantly growing } \\
\text { and its production is profitable }\end{array}$ & $\begin{array}{l}\text { A significant part of the investment from the start of the } \\
\text { project to the start of commercial production }\end{array}$ \\
\hline & $\begin{array}{l}\text { "Know how" used in the manufacturing of insulin can be exploited } \\
\text { to produce a number of other recombinant therapeutic peptides }\end{array}$ & $\begin{array}{l}\text { The need for highly qualified staff. The need to create a } \\
\text { modern logistic system and distribution network }\end{array}$ \\
\hline \multirow{4}{*}{$\begin{array}{l}\text { External } \\
\text { factors }\end{array}$} & Opportunities (0) & Threats (T) \\
\hline & $\begin{array}{l}\text { Recombinant insulin has been used effectively in the treatment of } \\
\text { diabetes for over } 30 \text { years. Diabetics use IRT with a consistent } \\
\text { increase in the dose of insulin. The number of patients who need } \\
\text { insulin for life is constantly growing }\end{array}$ & $\begin{array}{l}\text { An increase in production and sales of branded and new } \\
\text { rl products is possible. Growth in regional and global } \\
\text { markets for GLM (other than insulin), both oral and } \\
\text { parenteral }\end{array}$ \\
\hline & $\begin{array}{l}\text { Patent protection of an innovation technology. The lack of } \\
\text { competition for the product for more than } 10 \text { years. } \\
\text { Shorter term and lower research costs for biosimilar insulin }\end{array}$ & $\begin{array}{l}\text { Possible delays in the process of drug registration. } \\
\text { There may be problems with the marketing of the } \\
\text { product }\end{array}$ \\
\hline & $\begin{array}{l}\text { In principle, it is possible to use less expensive forms for } \mathrm{rl} \\
\text { delivery }\end{array}$ & $\begin{array}{l}\text { Opposing activities of direct and indirect competitors or } \\
\text { distributors. Competitors may attempt to dump the } \\
\text { prices }\end{array}$ \\
\hline
\end{tabular}

Note. IRT - insulin replacement therapy; $r I$ - recombinant insulin; GLM - glucose-lowering medications. 
Table 3. PEST analysis of factors crucial for initiation of recombinant insulin production.

\begin{tabular}{|c|c|}
\hline Factors & General and specific features \\
\hline Political & $\begin{array}{l}\text { - Type of the political system, its stability; } \\
\text { - Legal foundations of state administration; } \\
\text { - Adherence to the law and freedom of enterprise; } \\
\text { - Level of corruption; } \\
\text { - Protection of budget-forming resources }\end{array}$ \\
\hline Economical & $\begin{array}{l}\text { - Stability of the financial system in the country; } \\
\text { - The investment climate and economy growth potential; } \\
\text { - The role of the industrial component in the country's economy; } \\
\text { - Types and amounts of taxes; } \\
\text { - Level of development and methods of regulation of the pharmaceutical market; } \\
\text { - Capacity of the pharma market, medical services, forecast for their development; } \\
\text { - The model of the available insulin therapy; } \\
\text { - The national "Diabetes" program and its funding; } \\
\text { - Health insurance guarantees and its relevant budget }\end{array}$ \\
\hline Social & $\begin{array}{l}\text { - Demography and gender structure of the population; } \\
\text { - Social program and protection of workers' rights; } \\
\text { - Health care harmonization and expected reforms to improve patient QALY; } \\
\text { - Number of diabetic patients, trained experts in diabetes care or qualified endocrinologists, contacts with specialists; } \\
\text { - Public awareness of health problems, contacts with patients, access to information about therapeutic medicines; } \\
\text { - Activity of national and public associations that protect the rights of people with diabetes }\end{array}$ \\
\hline Technological & $\begin{array}{l}\text { - Scientific and technological potential, level of education; } \\
\text { - Qualified personnel for biopharmaceutical production and bioengineering; } \\
\text { - Government support for technological and industrial progress; } \\
\text { - Investment in science and technology; } \\
\text { - Availability of modern equipment and materials; } \\
\text { - Adherence to the standards of diabetes care; } \\
\text { - Opportunities for clinical research and certification; } \\
\text { - Network of pharmacies and distributors, facilities for storage and delivery of pharmaceuticals, up-to-date logistics; } \\
\text { - High level of information technology and automation; } \\
\text { - Measures for protecting and preserving the environment }\end{array}$ \\
\hline
\end{tabular}

making these decisions. Professionally prepared SWOT- and PESTanalyses will help in the development of strategic goals and planning of financing mechanisms for producing and selling the $\mathrm{rl}$ in countries with LND.

Before starting a rl pharmaceutical project, it is advisable that the investors, supervisors, and other interested parties assess the feasibility of the "Insulin production" project considering specific factors and national priorities.

Of major factors for considerations regarding the rl production are the safety and efficacy of insulin therapy that provide a high QALY (Quality Adjusted Life Years) score [67].

\section{Social and economic benefits of producing recombinant biological} products

In order to assess the socio-economic importance of BPrl, its direct contribution to the pharmaceutical sector and its impact on the community health and the regional economy should be analyzed. From the above, one can clearly see the positive consequences of the BPrl for health care in countries with LND; among those, the efficacy of IRT, the quality of life of patients with diabetes, the increase in the number of healthy newborns, the healthcare cost reduction and independence on the supply of imported medicines. In addition, BPrl directly and indirectly stimulates the development of infrastructure, technologies and economic activity in the region, reduces the import,-and increases the employment and employee incomes, resulting in increased tax deductions (Table 4). This development is also associated with modernization of the structures related to the $\mathrm{BPrl}$ and similar innovative technologies; indirectly, it involves educational progress, additional training activities and improvements in modern communications.
The importance of the BPrl is directly demonstrated in Table 4 where the data for insulin production were adjusted to the report by PhRMA (International Federation of Pharmaceutical Manufacturers \& Associations) in 2017 [47] on the economic aspects of biotherapeutic industry. According to this report, more than 800 thousand people are employed in the US biopharmaceutical sector, with about 300 thousand employees directly involved in the production, and each employee creates sales of nearly 2 million USD a year (see Table 4). Biopharmaceutical production stimulates a nearly fivefold increase in the indirect employment in the region (see Table 4) and provides a significant increase in the investments [47]. In 2014, 7300 employees at the Frankfurt-Höchst (Sanofi) factory produced insulin (Lantus) for $€ 6.1$ billion in selling prices. Such production stimulated the creation of 46.4 thousand indirect jobs. Similarly, to produce Glargin-type insulin for $€ 1.5$ billion, about 2 thousand skilled personnel is required, which will create more than 11 thousand jobs in the region. From the computational model (Table 4) it can be seen that the sale of Lantus insulin for $€ 6$ bln per year, about $€ 6.5$ bln of investment will return to the region only in taxes for 10 years of sales. In addition, the revenue from active sales could reach 10 billion USD over five years. Consequently, the production of insulin blockbusters has a positive impact on health care and economy, and also stimulates the progress of technology in the region.

\section{Rational approach to the purchase of recombinant insulin}

Due to the high costs of insulin, pharmacoeconomics of insulin is an important part of the health care system in countries with LND. With

\footnotetext{
Hohe Investitionen trotz rückläufiger Umsätze. [Electronic resource]. URL: https://www.fnp.de/wirtschaft/hohe-investitionen-trotz-ruecklaeufigerumsaetze-10874033.html. Accessed: 26.06.2019.
} 
Table 4. Direct and indirect impacts of insulin production on income and regional economy.

\begin{tabular}{|c|c|c|c|c|c|c|c|}
\hline \multirow{2}{*}{$\begin{array}{l}\text { Impact } \\
\text { Industry }\end{array}$} & \multirow{2}{*}{$\begin{array}{l}\text { Employment, } \\
\text { thousand }\end{array}$} & \multirow{2}{*}{$\begin{array}{l}\text { Output, } \\
\text { bln USD }\end{array}$} & \multirow{2}{*}{$\begin{array}{l}\text { Personal } \\
\text { Income, } \\
\text { bln USD }\end{array}$} & \multirow{2}{*}{$\begin{array}{c}\text { Personal Tax } \\
\text { Revenue, } \\
\text { bln USD }\end{array}$} & \multicolumn{3}{|c|}{ Total in the region } \\
\hline & & & & & $\begin{array}{l}\text { Employment, } \\
\text { thousand }\end{array}$ & $\begin{array}{l}\text { Output, } \\
\text { bln USD }\end{array}$ & $\begin{array}{c}\text { Personal Tax } \\
\text { Revenue, bIn USD }\end{array}$ \\
\hline $\begin{array}{c}\text { Biopharmaceutical industry } \\
\text { (US) [47] }{ }^{\star}\end{array}$ & 802,867 & 584.4 & 104 & 20.5 & $4,766.4$ & $1,319.3$ & 67.3 \\
\hline $\begin{array}{c}\text { Production Lantus, } \\
\text { (Sanofi-Aventis Deutschland } \\
\text { GmbH, Frankfurt-Höchst) }\end{array}$ & 7,8002 & 6.082 & 0.78 & 0.19 & 46.3 & 12.8 & 6.55 \\
\hline $\begin{array}{l}\text { Newcomer insulin } \\
\text { producer** }\end{array}$ & 1,924 & 1.5 & & & 11.42 & & \\
\hline
\end{tabular}

* In 2016, the USA industry exported more than $\$ 52$ billion in biopharmaceuticals [Pharmaceutical Research and Manufacturers of America (PhRMA) special 301 submissial 2018. Washington, DC: PhRMA. 179 p.].

** Personal income and tax may be unlike in different countries.

10 [https://www.fnp.de/wirtschaft/hohe-investitionen-trotz-ruecklaeufiger-umsaetze-10874033.html].

this approach, the cost-effectiveness of IRT is analyzed by comparing the cost of the treatment (financial component) and its results (positive dynamics of therapy, years of active life saved, QALY, etc.), thereby helping to achieve optimal distribution of health resources. The pharmacoeconomic analysis also considers the costs of research, development, certification, and production of therapeutic insulin. Randomized studies on pharmacoepidemiology and diabetic economics in the LND regions should help develop a rational therapeutic strategy with both the existing and new antidiabetic drugs. The "therapeutic effect / cost" analysis is fundamental for determining the model of diabetes management [46, 67-68]. Based on this analysis, national guidelines for optimal diabetes management are created. In any case, the financial constraints should not be decisive for choosing the type of therapy; rather, the recommendations of endocrinologist or family doctor are the most important considerations to get optimal QALY [4, 46, 67-68]. The quality of life with diabetes is higher in patients diagnosed at the early stages of the disease and those who receive timely treatment using reliable standard methods. The unavailability of insulin remains one of the major obstacles to the successful treatment of DM and may lead to incurable complications, disability and premature death.

Taking into account the practical recommendations of experts in pharmacoepidemiology and pharmacoeconomics, one can assess the number of patients in need of IRT and also the demand for a specific type of insulin in countries with LND.

As noted above, insulin is the only hormone that acts quickly and effectively against hyperglycemia of any etiology [3-4, 6]. The need for insulin continues to rise (see Fig. 1) due to the population growth, the expansion of the market and the transition of diabetic patients with T2DM to insulin therapy. According to the analysts, the demand for IRT will increase significantly in the following years, especially in countries with LND which import insulin in large quantities [65]. Therefore, for each of these countries (see Fig. 2), it is important to determine the timely procurement program for therapeutic $\mathrm{rl}$ (see Table 1), starting from the training specialists in pharmacoepidemiology and pharmacoeconomics.

Tables 1, 2 and 4 show that, on the one hand, the industrial production of the insulin API is costly and can be profitable only over a period of several years; on the other hand, the BPrl has given a systemic positive effect on the health of the community and leads to socio-economic progress of the entire region. Experts in pharmacoepidemiology and pharmacoeconomics should conduct a financial evaluation of diabetes therapy in countries with LND (see Fig. 2) by using modern methods of planning, medical statistics and modeling as well as considering the individual sensitivity of patients [4, 46, 67-70]. On this basis, they will calculate the demand for IRT, estimate the expenses and present the recommendations to the interested parties. In addition, practical approaches (see Tables 1-3) and the experience with pharmacoeconomics of $\mathrm{rl}$ can be used as a model for upgrading the procurement system for other expensive biopharmaceuticals.

\section{Conclusion}

Modern pharmacoeconomic analysis helps, especially in large importing countries, improve the supply of biologics necessary for IRT or other types of biopharmaceutical therapy in order to improve the QALY of patients with DM. Specifically, experts in pharmacoeconomics of insulin are needed to optimize the IRT and improve the procurement strategy for insulin - a life-saving drug according to the WHO.

Until now, decades-long studies by several groups have not resulted in the creation of an effective artificial or bio-analogous pancreas to compensate for insulin deficiency or to stimulate the insulin synthesis with stem cells [3, 71-73]. Exogenous rl remains the most effective and natural glucose-lowering medication. To make the insulin therapy affordable in LND countries with low and low-middle income, it is necessary to significantly reduce its cost. To achieve this goal, revolutionary changes in IRT technology are needed. The ways to create an innovative IRT include: research into new types of $\mathrm{rl}[71,74-$ 76], minimizing the production expenditure, improvements in the upstream and down-stream processes [77-84], as well as to apply advanced and inexpensive methods of the drug delivery [85-90].

Pharmacoeconomic analysis provides a comprehensive picture of diabetes management: it incorporates the Economic, Clinical and Humanistic Outcomes, abbreviated as ECHO.

The ECHO approach was recently used to analyze the availability of insulin therapy and the need for the production of $\mathrm{rl}$ in countries of the Eurasian Union [91]. This analysis (see Fig. 3-5, Tables 1-3) suggests that countries with low regulation of the pharmaceutical market and with insufficient funding for the Diabetes program (e.g., Bangladesh and Pakistan) will be importing the main part of $\mathrm{rl}$ for a long time. Countries with LND with a responsible policy toward the IRT (see Fig. 3-5) and a high level of regulation of the pharmaceutical market (Germany and Japan) can produce several types of $r l$ in the blockbuster volumes. Due to the political situation, the Iranian government intends to independently produce important genetically engineered drugsk, including the $\mathrm{rl}$, which, in principle, is possible based on the SWOT and PEST analyses (see Table 2-3). For countries with a growth-oriented pharmaceutical market (Brazil, China, Russia, Turkey), their own production of modern recombinant insulin in required volumes is feasible not only in the future, but also in the present, pending the necessary government support as specified in the PEST analysis (Table 3). The inexpensive production of biopharmaceutical insulin makes the IRT available in the countries with LND for most patients, increases their QALY, and stimulates the development of new technologies that improve health care, economy, budget stability and social climate of the local community and the entire country.

k [Electronic resource].URL: https://financialtribune.com/articles/people/26779/ iran-big-market-for-insulin-production-export. Accessed: 26.06.2019. 


\section{References:}

1. Guidelines on second- and third-line medicines and type of insulin for the control of blood glucose levels in non-pregnant adults with diabetes mellitus. Geneva: World Health Organization. 2018.

2. Global report on diabetes. World Health Organization. Geneva. 2016.

3. Textbook of diabetes (ed by: Holt R.I.G, Cockram C.S., Flyvbjerg A., Goldstein B.J.) Fifth edition. Wiley-Blackwell. 2017. $1104 \mathrm{p}$.

4. Classification and Diagnosis of Diabetes: Standards of Medical Care in Diabetes - 2019. American Diabetes Association. Diabetes Care. 2019; 42 (S1): S13-S28. D0l: https://doi.org/10.2337/dc19-S002.

5. IDF DIABETES ATLAS Eighth edition. International Diabetes Federation. 2017; [Electronic resource] URL: https://www. diabetesatlas.org. Accessed: 03.07.2019.

6. Crasto W., Jarvis J., Davies M. J. Handbook of Insulin Therapies. Springer. 2016; 209 p.

7. Davies M. J., D'Alessio D.A., Fradkin j., Walter N. Kernan W. N., et al. Management of Hyperglycemia in Type 2 Diabetes, 2018. A Consensus Report by the American Diabetes Association (ADA) and the European Association for the Study of Diabetes (EASD). Diabetes Care. 2018; 41: 2669-2701. DOI: https://doi.org/10.2337/dci18-0033.

8. Landgraf W., Sandow J. Recombinant Human Insulins - Clinical Efficacy and Safety in Diabetes Therapy. European Endocrinology. 2015; 12 (1): 1-6. DOI: 10.17925/EE.2016.12.01.12.

9. Bommer C., Sagalova V., Heesemann E., et al. Global Economic Burden of Diabetes in Adults: Projections From 2015 to 2030. Diabetes Care. 2018; 41 (5): 963-970. D0l: https://doi.org/10.2337/dc17-1962.

10. Cefallu W. T., Dawes D. E., Gavlak G., Goldman D., Herman W. H., et.al. Insulin Access and Affordability Working Group: Conclusions and Recommendations. Diabetes Care. 2018; 41 (6): 1299-1311. doi: 10.2337/dci18-0019.

11. Seuring T., Arachangel O., Suhrcke M. The economic costs of type 2 diabetes: A global systematic review. Pharm. Econ. 2015; 33 : 811-831.

12. Beran D., Ewen M., Lepeska M., Laing R. Access to insulin: current challenges and constraints. Health Action International. 2017; [Electronic resource] URL: www.haiweb.org Accessed: 03.07.2019.

13. Ewen M, Joosse H-J, Beran D., Laing R. Insulin prices, availability and affordability in 13 low-income and middle-income countries. BMJ Global Health. 2019;4:e001410. [Electronic resource] URL: https://gh. bmj.com/content/bmjgh/4/3/e001410.full.pdf Accessed: 03.07.2019 doi:10.1136/bmjgh-2019-00141.

14. Maier K., Riley M. Improving Insulin Access and Affordability/ADA 2018; 1-15. [Electronic resource] URL: http://www.diabetes.org/ assets/pdfs/advocacy/improving-insulin-access-and.pdf. Accessed: 03.07.2019.

15. American Diabetes Association $®$ Reaffirms Commitment to Insulin Access and Affordability for All - Transparency on Insulin Pricing Critical. 2018; [Electronic resource] URL: http://www.diabetes. org/newsroom/press-releases/2018/insulin-access-affordabilitytransparency-critical.html Accessed: 03.07.2019.

16. Beran D. The Rapid Assessment Protocol for Insulin Access (RAPIA): Research for Action on Access to Diabetes Care RG2004. 2009; [Electronic resource] URL: https://www.researchgate.net/ publication/228381768. Accessed: 03.07.2019.

17. Economic Costs of Diabetes in the U.S. in 2017. Diabetes Care. 2018; 41: 917-928. DOI: https://doi.org/10.2337/dci18-0007.

18. Pedron S., Emmert-Fees K., Laxy M., SchwettmannL. The impact of diabetes on labour market participation: a systematic review of results and methods. BMC Public Health. 2019; 19: 1-13. DOl: https://doi.org/10.1186/s12889-018-6324-6.

19. Kähm K., Laxy M., Schneider U., Rogowski W.H., Lhachimi S. K., Holle R. Health care costs associated with incident complications in patients with type 2 diabetes in Germany. Diabetes Care. 2018; 41: 971978. DOl: https://doi.org/10.2337/dc17-1763.
20. Mbanya J. C., Sandow J., Landgraf W., OwensD.R. Recombinant Human Insulin in Global Diabetes Management - Focus on Clinical Efficacy. European Endocrinology. 2017; 13 (1): 21-25. D0I: https:// doi.org/10.17925/EE.2017.13.01.21.

21. Riddle M. C., Herman W.H. The Cost of Diabetes Cared An Elephant in the Room. Diabetes Care. 2018; 41: 929-932. DOI: https:// doi.org/10.2337/dci18-0012.

22. Ogurtsova K., J.D. Fernandes J.D., Huang Y., Linnenkamp U., et al. IDF Diabetes Atlas: Global estimates for the prevalence of diabetes for 2015 and 2040. Diabetes Research and Clinical Practice. 2017; 128: 40-50.

23. Liebl A., Khunti K., Orozco-Beltran D., Yale J.-F. Health Economic Evaluation of Type 2 Diabetes Mellitus: A Clinical Practice Focused Review. Clinical Medicine Insights: Endocrinology and Diabetes. 2015; 8: 13-19. DOI:10.4137/CMED.S20906.

24. Petrides D. Bioprocess Design and Economics. Bioseparations Science and Engineering 2nd Edition (ed by: Harrison R. G., Todd P. W., Rudge S.R., Petrides D.P.). Oxford University Press. 2015; 11.111.83.

25. Rotenstein K.S., Ran N.R., Shivers J.P., Yarchoan M., Close K. L. Opportunities and Challenges for Biosimilars: What's on the Horizon in the Global Insulin Market? Clinical Diabetes. 2012; 30 (4): 138-150.

26. Wirtz V.J. Insulin Market Profile 2016. Amsterdam: Health Action International: 104 p. [Electronic resource] URL: https://haiweb. org/wp-content/uploads/2016/04/ACCISS_Insulin-Market-Profile_ FINAL.pdf. Accessed: 03.07.2019.

27. Assessment report EMA/CHMP/340840/2014. Abasria/ International non-proprietary name: insulin glargine Procedure No. EMEA/H/C/002835/0000. [Electronic resource] URL: https://www. ema.europa.eu/en/documents/assessment-report/abasria-eparpublic-assessment-report_en.pdf. Accessed: 03.07.2019.

28. Mylan and Biocon Announce Regulatory Submission for Insulin Glargine Accepted for Review by European Medicines Agency 2016. [Electronic resource] URL: http://newsroom.mylan.com/2016-11-03Mylan-and-Biocon-Announce-Regulatory-Submission-for-InsulinGlargine-Accepted-for-Review-by-European-Medicines-Agency Accessed: 03.07.2019.

29. Merck Announces U.S. FDA Filing Acceptance of New Drug Application (NDA) for MK-1293, an Investigational Follow-On Biologic Insulin Glargine 2016. [Electronic resource] URL: https://www. mrknewsroom.com/news-release/research-and-development-news/ merck-announces-us-fda-filing-acceptance-new-drug-application Accessed: 03.07.2019.

30. Ewen M., Joosse H.-J., Ashigbie P., Beran D., Laing R. Insulin Prices Profile. 2016: 155 p. Amsterdam: Health Action International. [Electronic resource] URL: www.haiweb.org. Accessed: 03.07.2019.

31. Kuhlmann M.K., Schmidt A. Production and manufacturing of biosimilar insulins: implications for patients, physicians, and health care systems. Biosimilars. 2014; 4: 45-48.

32. Davies M., Dahl D., Heise T., Kiljanski J., Mathieu C. Introduction of biosimilar insulins in Europe. Diabet. Med. 2017; 34: 1340-1353.

33. Sandow J., Landgraf W., Becker R., Seipke G. Equivalent Recombinant Human Insulin Preparations and their Place in Therapy Diabetes. European Endocrinology. 2015; 11 (1): DOI: 10.17925/ EE.2015.11.01.10.

34. Derwahl K.M., Bailey T. S., Wernicke-Panten K., Ping L., Pierre S. Efficacy and Safety of Biosimilar SAR342434 Insulin Lispro in Adults with Type 2 Diabetes, Also Using Insulin Glargine: SORELLA 2 Study. DTT. 2018; 20 (1): DOI: 10.1089/dia.2017.0281.

35. Owens D.R., Traylor L., Mullins P., Landgraf. W. Patient-level meta-analysis of efficacy and hypoglycaemia in people with type 2 diabetes initiating insulin glargine $100 \mathrm{U} / \mathrm{mL}$ or neutral protamine 
Hagedorn insulin analysed according to concomitant oral antidiabetes therapy. Diabetes Res Clin Pract. 2017; 124: 57-65.

36. Tieu C., Lucas E.J., DePaola M., Rosman L., Alexander G. C. Efficacy and safety of biosimilar insulins compared to their reference products: A systematic review. PLOS ONE 2018; 13(4): e0195012. [Electronic resource] URL: https://journals.plos.org/plosone/ article?id=10.1371/journal.pone.0195012. Accessed: 03.07.2019. DOI: https://doi.org/10.1371/journal.pone.0195012.

37. Hua X., Carvalho N., Tew M., et al. Expenditures and Prices of Antihyperglycemic Medications in the United States: 2002-2013. JAMA. 2016; 315 (13): 1400-1402. DOI:10.1001/jama.2016.0126.

38. Holden S. E., Poole C. D., Morgan C. L., Currie C. J. Evaluation of the incremental cost to the National Health Service of prescribing analogue insulin. BMJ Open. 2011; 2: 1-7.

39. Heinemann L. Insulin Pens and New Ways of Insulin Delivery. DTT. 2013; 15: Supplement 1. S48-S59. D0I: 10.1089/dia.2013.1506.

40. Cafasso J. Insulin Prices: Pumps, Pens, Syringes, and More. 2018. [Electronic resource] URL: https://www.healthline.com/health/ type-2-diabetes/insulin-prices-pumps-pens-syringes Accessed: 03.07.2019.

41. Sorli C., Heile M.K. Identifying and meeting the challenges of insulin therapy in type 2 diabetes. J. Multidiscip. Healthcare. 2014; 7 : 267-282.

42. Russell-Jones D., Gall M.-A., Niemeyer M., Diamant M., Del Prato S. Insulin degludec results in lower rates of nocturnal hypoglycaemia and fasting plasma glucose vs. insulin glargine: a meta-analysis of seven clinical trials. Nutr Metab Cardiovasc Dis. 2015; 25: 898-905.

43. Silva T.B.C., Almeida P.H.R.F., Araújo V.E., De Assis Acurcio F., et al. Effectiveness and safety of insulin glargine versus detemir analysis in patients with type 1 diabetes: systematic review and metaanalysis. Ther Adv Endocrinol Metab. 2018; 9(8): 241-254.

44. Hasslacher C., Bermejo J.L. Treatment with insulin analogs and prevalence of cardiovascular complications in patients with type 1 diabetes. Ther Adv Endocrinol Metab. 2017; 8 (11): 149-157. DOI: $10.1177 / 2042018817732732$.

45. Bjekic'-Macut J., Z'ivkovic' T.B., Kocic R. Clinical Benefit of Basal Insulin Analogue Treatment in Persons with Type 2 Diabetes Inadequately Controlled on Prior Insulin Therapy: A Prospective, Noninterventional, Multicenter Study. Diabetes Ther. 2018; 9: 651-662. https://doi.org/10.1007/s13300-018-0378-4.

46. Tricco A. C., Ashoor H. M., Antony J., Beyene J., et al. Safety, effectiveness, and cost effectiveness of long acting versus intermediate acting insulin for patients with type 1 diabetes: systematic review and network meta-analysis. BMJ. 2014; 349: g5459. [Electronic resource] URL: $\quad$ https://www.ncbi.nlm.nih.gov/pmc/articles/PMC3847127/ pdf/2046-4053-2-73.pdf. Accessed: 03.07.2019.

47. The Economic Impact of the U.S. Biopharmaceutical Industry: 2015 National and State Estimates. PhRMA_GoBOLDLY. 2017; Pharmaceutical Research and Manufacturers of America (PhRMA) special 301 submissial 2018. Washington, DC: PhRMA. 179 p.

48. Gurramkonda C., Polez S., Skoko N., Adnan A., Gabel T., et al. Application of simple fed-batch technique to high-level secretory production of insulin precursor using Pichia pastoris with subsequent purification and conversion to human insulin. Microbial Cell Factories. 2010; 9: 31-42. http://www.microbialcellfactories. com/content $/ 9 / 1 / 31$

49. Kroeff E.P., Owenes R.A., Campbell E.L., Johnson R.D., Marks H. I. Production scale purification of biosynthetic human insulin by reversed-phase high-performance liquid chromatography. Journal of Chromatography. 1989; 461: 45-61

50. Petrides D., Sapidou E., Calandranis J. Computer-Aided Process Analysis and Economic Evaluation for Biosynthetic Human Insulin Production - A Case Study. Biotechnol Bioeng. 1995; 48 (5): 529-541.
51. Krämer I., Sauer T. The new world of biosimilars: what diabetologists need to know about biosimilar insulins. British Journal of Diabetes \& Vascular Disease. 2010; 10: 163-171.

52. Nilsson J., Jonasson P., Samuelsson E., Stähl S., Uhlen M. Integrated production of human insulin and its C-peptide. Journal of Biotechnology. 1996; 48: 241-250.

53. Gallegos J.E., Boyer C., Pauwels E., Kaplan W.A., Peccoud J. The Open Insulin Project: A Case Study for 'Biohacked' Medicines. Trends in Biotechnology. 2018; 36 (12): 1211-1218. DOl: https://doi. org/10.1016/j.tibtech.2018.07.009.

54. Baeshen N. A., Baeshen M. N., Sheikh A., Bora R. S., et al. Cell factories for insulin production. Microbial Cell Factories. 2014; 13: 141-149. http://www.microbialcellfactories.com/content/13/1/141.

55. Polez S., Origi D., Zahariev S., Guarnaccia C., Tisminetzky S. G., Skoko N., Baralle M. A Simplified and Efficient Process for Insulin Production in Pichia pastoris. PLOS ONE. 2016; 11 (12): 1-15.

56. Petrides D. P., Koulouris A., Lagonikos P.T. The Role of Process Simulation in Pharmaceutical Process Development and Product Commercialization. Ispe pharmaceutical engineering $\circledast$. 2002; 22 (1): $1-8$.

57. Risk Management Applications in Pharmaceutical and Biopharmaceutical Manufacturing. (Ed by Mollah H., Baseman $\mathrm{H}$., Long M. John Wiley \& Sons, Inc. 2013; 416 p.

58. Gulf Pharmaceutical Industries (Julphar) Insulin Production Facility. [Electronic resource] URL: https://www.pharmaceuticaltechnology.com/projects/gulf-pharmaceutical-industries-julpharinsulin-production-facility-uae/. Accessed: 03.07.2019.

59. Patent WO 2012/098009. Chimeric Polypeptide comprising a Membrane Protein and an Insulin Precursor. Ponomarenko S. Applicant GlucoMetrix AG. Priority Date: 21.01.2011; International Filling: 20.01.2012 PCT/EP2012/000266.

60. Kaplan W., Beall R. Insulin Patent Profile. Amsterdam: Health Action International. 2016.

61. Rasmussen B. Innovation and Commercialisation in the Biopharmaceutical Industry: Creating and Capturing Value. Edward Elgar Publishing Ltd. 2010; 326 p.

62. Anderlei T., Eibl D., Eibl R., Eisenkrätzer D. Facility of the Future. 2017. Dehema. 35 p.

63. Lütke-Eversloh T., Rogge P. Biopharmaceutical manufacturing in single-use Bioreactors. Current status and challenges from a CDMO perspective. Pharm. Ind. 2018; 80 (2): 281-284.

64. Gotham D., Barber M. J., Hill A. Production costs and potential prices for biosimilars of human insulin and insulin analogues. BMJ Glob Health. 2018; 3:e000850. [Electronic resource] URL: https://gh. bmj.com/content/bmjgh/3/5/e000850.full.pdf. Accessed: 03.07.2019. doi: 10.1136/bmjgh-2018-000850.

65. Seidenader N. Trend \& market report. Insights into the diabetes\& insulin market. Brainnovative Consulting e.V. 2016; 32 p.

66. Lee J. PEST and NET analysis of biopharmaceutical industry. ICI Meeting 2015. [Electronic resource] URL: http://2015.icimeeting.com/ e-posters/pdf/22.pdf. Accessed: 03.07.2019.

67. Fernandes J., Zhang P. COST-EFFECTIVE AND COST-SAVING INTERVENTIONS FOR PREVENTION AND CONTROL OF DIABETES. Diabetes Voice. 2016; 62 (2): 16-20.

68. Pease A., Lo C., Earnest A., Liew D., Zoungas S. Evaluating optimal utilization of technology in type 1 diabetes mellitus from a clinical and health economic perspective: protocol for a systematic review. Systematic Reviews. 2018; 7: 44. DOI: https://doi.org/10.1186/ s13643-018-0706-9

69. Ourth H., Nelson J., Spoutz P., Morreale A.P. Development of a Pharmacoeconomic Model to Demonstrate the Effect of Clinical Pharmacist Involvement in Diabetes Management. J Manag Care Spec Pharm. 2018; 24 (5): 449-457.

70. Keeney E., Dawoud D., Dias S. Different Methods for Modelling Severe Hypoglycaemic Events: Implications for Effectiveness, Costs 
and Health Utilities. PharmacoEconomics. 2018; 36: 523-532. DOI: https://doi.org/10.1007/s40273-018-0612-y.

71. Bailey T.S., Walsh J., Stone J.Y. Emerging Technologies for Diabetes Care. DTT. 2018; 20 (S 2): S2.78-S2.84.

72. Lawton J., Blackburn M., Rankin D., Allen J., Campbell F, et al. Research: Educational and Psychlogical Aspects The impact of using a closed-loop system on food choices: a qualitative study involving adults, teenagers and parents. Diabet. Med. 2019; 36; 753-760. DOI: 10.1111/dme 13887.

73. Bekiari E., Kitsios K., Thabit H., Tauschmann M., et al. Artificial pancreas treatment for outpatients with type 1 diabetes: systematic review and meta-analysis. BMJ. 2018; 361: k1310. [Electronic resource] URL: http://dx.doi.org/10.1136/bmj.k1310. Accessed: 03.07.2019.

74. Rege N.K., Wickramasinghe N.P., Tustan A. N., Phillips N. F.B., Yee V.C., Ismail-Beigi F., Weiss M. A. Structure-Based Stabilization of Insulin as a Therapeutic Protein Assembly via Enhanced AromaticAromatic Interactions. J Biol.Chem. 2018; 293: [Electronic resource] URL: http://www.jbc.org/content/293/28/10895. Accessed: 03.07.2019.

75. Zaykov A. N., Mayer J.P., DiMarchi R.D. Pursuit of a perfect insulin. Nature Rev. Drug Discovery. 2016; 15: 425-439.

76. Mikiewicz D., Bierczynska-Krzysik A., Sobolewska A., Stadnik D., Bogiel M., et al. Soluble Insulin Analogs Combining Rapidand Long-acting Hypoglycemic Properties - From an Efficient E. coli Expression System to a Pharmaceutical Formulation. PLoS One. 2017; 12 (3): e0172600. [Electronic resource] URL: https://journals.plos.org/ plosone/article?id=10.1371/journal.pone.0172600. Accessed: 03.07.2019. DOI: 10.1371/journal.pone.0172600.

77. Patent WO 2012/048856 A1. Proinsulin with helper sequence. Ponomarenko S., Hermann S., Eckert K. Applicant GlucoMetrix AG. Priority Date: 12.10.2010; International Filling: 11.10.2011 PCT/ EP2011/005090.

78. Hwang H.G, Kim K.-J., Lee S.-H., Kim C.-K., et al. Recombinant glargine insulin production process using Escherichia coli. JMB. 2016; 10: 1781-1789.

79. Sreenivas S., Krishnaiah S. M., Govindappa N., Basavaragu Y., et al. Enhancement in production of recombinant two-chain insulin glargine by over-expression of Kex2 protease in Pichia pastoris. Appl. Microbiol. Biotechn. 2015; 99(1): 327-336. [Electronic resource] URL: DOI 10.1007/s 00253-014-6052-5. Accessed: 03.07.2019.

80. High-throughput process development and scale-up of an intermediate purification step for recombinant insulin. GE Healthcare
Life Sciences. [Electronic resource] URL: http://www. processdevelopmentforum.com/articles/high-throughput-processdevelopment-and-scale-up-of-an-intermediate-purification-step-forrecombinant-insulin/. Accessed: 03.07.2019.

81. Kim C.-K., Lee S.-B., Son Y.-J. Large-Scale Refolding and Ezyme Reaction of Human Preproinuslin for Production of Human Insulin. J Microbiol Biotechnol. 2015; 25 (10): 1742-1750. Doi: http:// dx.doi.org/10.4014/jmb.1504.04062.

82. Chen Y., Wang Q., et al. Improving the refolding efficiency for proinsulin aspart inclusion body with optimized buffer compositions. Protein Expression and Purification. 2016; 122: 1-7.

83. Gusarov D., Nekipelova V., Gusarova V., Lasman V., Bairamashvili D. Displacement effect during HPLC preparative purification of human insulin. J Chromatogr Analyt Technol Biomed Life Sci. 2009; 87 (7): 1216-1220.

84. Nanev C., Petrov K.P. Steering a crystallization process to reduce crystal polydispersity; case study of insulin crystallization. Journal of Crystal Growth. 2017; 480: 164-169.

85. Rege N.K., Weiss M.A., Phillips N.F.B. Development of Glucose-Responsive "Smart" Insulin Systems. Curr Opin Endocrinol Diabetes Obes. 2017; 24 (4): 267-278. DOI: 10.1097/MED.

86. Bally L., Thabit H., Kojzar H., Mader J.K., et al. Day-and-night glycaemic control with closed-loop insulin delivery versus conventional insulin pump therapy in free-living adults with well controlled type 1 diabetes: an open-label, randomized, crossover study. Lanzet Diabetes Endocrin. 2017; 5: 261-270.

87. Thueer T., Birkhaeuer L., Reilly D. Development of an advanced injection time model for an autoinjector. Med. Devices:Evid. Research. 2018; 11: 215-224.

88. Lange J., Urbanek L., Burren S. Development of devices for selfinjection: using tribological analysis to optimize injection force. Med. Devices:Evid. Research. 2016; 9: 93-103.

89. Dadlani V., Pinsker, J.E., Dassau E., C. Kudva, Y. C. Advances in Closed-Loop Insulin Delivery Systems in Patients with Type 1 Diabetes. Current Diabetes Reports. 2018; 18 (10): [Electronic resource] URL: 18. 10.1007/s11892-018-1051-z. Accessed: 03.07.2019.

90. Gedawy A., Martinez J., Al-Salami H., Dass C.R. Oral insulin delivery: existing barriers and current counter-strategies. JPP. 2017; 70: 197-213. DOI: 10.1111/jphp.12852.

91. Ponomarenko S. V., Chshankin M.A. Impact of economic and medico-social factors on accessibility of insulin therapy for patients with diabetes mellitus in the CIS countries. Russian Journal of Biopharmaceuticals. 2018; 10 (6): P. 3-11.

\section{About the authors:}

Sophia V. Ponomarenko - Project Manager at SophiGen, and InsuPharma AG, Boenen, Germany. E-mail: ponomarenko@t-online.de.

\section{Сведения об авторе:}

Пономаренко София Васильевна - руководитель проекта в СофиГен и Инсу-Фарма АГ, Бёнен, Германия. E-mail: ponomarenko@t-online.de. 